\title{
Understanding European Union Science Diplomacy ${ }^{1}$
}

\author{
ALEA LÓPEZ DE SAN ROMÁN ${ }^{1}$ AND SIMON SCHUNZ ${ }^{2}$ \\ ${ }^{1}$ League of European Research Universities (LERU). ${ }^{2}$ College of Europe
}

\section{Introduction}

For a number of years, the European Union (EU) has attempted to expand its rather hands-on international science and technological cooperation activities, which have been the external face of its internal funding policies around the framework programme for research, to a genuine EU "science diplomacy" (Commission 2012b; Prange-Gstöhl 2010). A generally accepted definition identifies three dimensions of such science diplomacy: (i) science in diplomacy (how science can inform foreign policy objectives), (ii) diplomacy for science (how diplomatic activities can facilitate international science cooperation), and (iii) science for diplomacy (using science to improve international relations) (Royal Society 2010: v-vi). While the first dimension points to a science-foreign policy nexus in areas where scientific insights shape foreign policy (e.g. environmental diplomacy), the second dimension embodies primarily the classical understanding of science and technological (S\&T) cooperation, and the third dimension points to a use of science in foreign policy contexts "as an effective agent to manage conflicts, improve global understanding, lay grounds for mutual respect and contribute to capacity-building" (Flink/Schreiterer 2010: 665). It is the latter two dimensions of its science diplomacy that the EU has arguably most vigorously attempted to reinforce.

\footnotetext{
${ }^{1}$ The authors would like to thank the three anonymous referees for their constructive comments.
} 
Although the EU has been engaged in international S\&T cooperation since the launch of the First Framework Programme in 1983, and a limited legal competence was introduced with the 1987 Single European Act (Art. 130n), "an international EU research policy or strategy hardly existed" until the 2008 Commission "Strategic European Framework for International S\&T Cooperation", providing a first "long-term structure to the EU's international S\&T policies" (Prange-Gstöhl 2010: 13). In 2012, the "Strategic Approach" to international cooperation in research and innovation reinforced this structure, identifying a range of EU external science policy tools such as S\&T Cooperation Agreements with third countries and engagement with international organisations (Commission 2012b). Especially since 2014, the EU has further promoted its external science-related activities: international cooperation represents a cross-cutting priority of the €79bn Horizon 2020 programme (2014-2020), and Research Commissioner Moedas has repeatedly expressed his desire "to see the EU play an increasingly active and visible role in international science diplomacy" (2016). "Open to the world" ("The EU strategy for global Research and Innovation cooperation and science diplomacy") is then also one of the three goals set by the Commissioner (Commission 2016: 6-7, 64). Science and research as subjects of diplomacy are also referred to multiple times in the EU's 2016 Global Strategy (EEAS 2016). The apparently growing salience of EU science diplomacy might confirm Prange-Gstöhl's supposition (2010: 227) that an evolution from an "external dimension of the ERA" (European Research Area) to an "EU external S\&T policy" is taking place.

This article strives to better understand this recent and under-researched development, asking how and why the Union seeks to extend the scope of its external activities in the ever more important science domain. Examining the external aspects of this originally internal policy is an increasingly 
pertinent subject not only because - under the 2014-2020 Multiannual Financial Framework science represents the EU's third biggest spending area after cohesion and agricultural policy, but also because its budgetary endowment illustrates policy-makers' understanding of science and innovation as a major catalyst of "growth and jobs" under the Europe 2020 strategy. To search for possible motivations for the external expansion of its activities, it starts with a look into the emergent literature on science diplomacy and links this to the EU external relations literature to ultimately embed the analysis into the major contemporary debate about whether the EU can best be considered as a market or a normative power.

Also beyond the EU context, the area of science diplomacy represents a rather recent field of activity (Flink/Schreiterer 2010). Where international science cooperation was already pursued by several nation-states during the Cold War (see Lord/Turekian 2007; Wang 2014), countries such as France, Germany, Japan, the United Kingdom and the United States have only recently stepped up their engagements in science diplomacy (for an overview of national science diplomacies, see Flink/Schreiterer 2010), sparking some interest in the domain among International Relations (IR) scholars. One of the few existing studies concludes that the development of science diplomacy is generally driven by two rationales: competitiveness concerns in the context of globalisation and desires to foster cooperation (Flink/Schreiterer 2010). A country's choice for science diplomacy can thus be grounded in an interest-driven motivation to extend the reach of its science-related activities beyond national boundaries so as to compete on the global market for knowledge and talents or on the wish to exploit the potential of science by integrating it into foreign policy to enhance cooperation with third parties. 
When searching for the EU's motivations for developing its science diplomacy, the insights from the scarce literature on science diplomacy on the competiveness/cooperation dichotomy suggests itself as a reasonable point of departure. It resonates with - and can be linked to - the prominent debate in the area of EU external relations studies about the nature of the EU's power. This "EUas-power" debate has occupied a significant place in EU studies ever since Duchêne (1972) suggested that the EU could best be conceived of as a "civilian power". It revolved around various conceptualisations of the EU with different interpretations of the motivations for and key characteristics of its external action. The latest round of this debate involves the concepts of normative and market power Europe. For Manners (2002: 242), the EU may best be considered a "normative power" (NPE) and its "central component (...) is that it exists as being different to preexisting political forms, and that this particular difference predisposes it to act in a normative way" vis-à-vis the external world. The EU's normative foundations are embodied in five core norms (peace, liberty, democracy, rule of law, human rights) and four minor norms (social solidarity, anti-discrimination, sustainable development, good governance). From this perspective, EU external science activities would be motivated by the desire to promote its norms and characterised by a focus on norms in its attempts at cooperating with third countries. In opposition to Manners, Damro (2012) introduced the concept of "market power Europe" (MPE), perceiving the EU as essentially a large regulated market that wants other actors to adhere to levels of regulation similar to its own or to behave in ways that generally satisfy EU policies and regulations. From this perspective, EU external action in the science domain would be motivated by a desire to defend its interests and promote existing EU practices, policies and regulations globally. As a matter of fact, the EU is in the process of developing the European Research Area, a "unified research area open to the world based on the internal market, in which researchers, scientific knowledge and 
technology circulate freely" (Commission 2012a: 3). An objective of EU science diplomacy could therefore be to extend the reach of this "science market" because through ERA "the Union and its Member States strengthen their scientific and technological bases, their competitiveness and their capacity to collectively address grand challenges" (Commission 2012a: 3).

Both NPE and MPE can therefore help to account for how and why EU policy-makers strive to expand the scope of EU external science policies. Vice-versa, by examining the case of science diplomacy a meaningful contribution can be made to the NPE/MPE debate. Where this debate has quite regularly been characterised by proponents of one or the other concept examining cases through which the claims of their preferred "EU-as-power" image may best be proven (see, for instance, JEPP 2015; Whitman 2011), analyses of cases not readily falling into one or the other category have so far been scarce. Science diplomacy, as a rather recent phenomenon that prima facie does not suggest itself as a clearly norm- or interest-driven policy, represents such a "hard case".

If this article thus uses NPE and MPE as conceptual starting points for its investigation into the how and why of the EU's policy expansion in the area of science diplomacy, also with the intention of contributing to the salient "EU-as-power" debate, it makes the deliberate choice to concentrate on norms and interests as EU policy-makers' motivating factors. ${ }^{2}$ By proceeding in this way, it

\footnotetext{
${ }^{2}$ The choice to address what could ultimately be regarded as a classical case of deepening EU integration in this way - and not with recourse to EU integration theories - is justified by the significance of the "EU-as-power" debate and the focus on policy-makers' motivations in an area of potentially lower political salience (and thus not liberal intergovernmentalists" "high politics") and of more limited longevity.
} 
pursues two main purposes: besides developing an empirical understanding of this evolving policy field that clarifies the motivations for and conceptualisations of science diplomacy as diplomacy for science or science for diplomacy, it employs science diplomacy as a case for understanding whether the EU relies on interest-based utilitarianism or normative motives for expanding the scope of its external activities. This allows for a necessary nuancing of the debate opposing interests and a logic of instrumentalism (MPE) and norms and a logic of appropriateness (NPE) as sources and means of EU external action (Youngs 2004; Lavenex 2014). The article finds that NPE and MPE (and EU policy-makers' words and actions captured by these concepts) are not mutually exclusive, but can coexist, overlap and interact. It argues that the ambiguity of rationales invoked for promoting science diplomacy in an EU context actually helps to appeal to different constituencies. This, in turn, enhances the Union's chances for expanding the scope of its activities.

The article proceeds as follows: Section 2 introduces an analytical framework that defines science diplomacy and relates the NPE and MPE concepts to a set of nine role conceptions that the EU holds in external science policies. To explain these role conceptions, Section 3 reports the results of a discourse analysis on the reasons policy-makers from the EU institutions invoke to motivate the expanding scope of their activities in this domain. To validate the findings and assess the extent of congruence between the EU's words and deeds, section 4 probes into the Union's external science policies. Section 5 synthesises the findings and expands on their broader implications. 


\section{Analytical framework}

The evolution of science diplomacy can be traced both in EU policy-makers' rhetoric and practice. Following a conceptual clarification of what science diplomacy entails, this section introduces an analytical framework that allows for examining the EU's discourse, understood here as the framework through which policy-makers in the EU, that is, representatives of the EU's main institutions - the European Commission, the Council of the EU and the European Parliament -, provide justifications for engaging in science diplomacy, before probing into its action.

\section{Defining science diplomacy}

For some years, the concept of science diplomacy has gained ground in policy-makers' discourses and practice. Despite a slowly growing interest within IR, it remains an underexplored and "fluid concept" (Royal Society 2010: v). To define it, it has become customary to refer to the abovementioned, three-dimensional conceptualisation by the Royal Society and the American Association for the Advancement of Science that distinguishes between science in diplomacy, diplomacy for science and science for diplomacy (Royal Society 2010). Although all three dimensions refer to the science-foreign policy nexus, science in diplomacy touches on the more general question to what extent policies should be informed by scientific knowledge. This issue is not specific to foreign policy, but plays a role in numerous policy-making processes. By contrast, the other two dimensions, which this contribution focuses on, concern exclusively the relationship between science as subject of policies and foreign policy: "Diplomacy for Science [implies] formal diplomatic means to achieve scientific goals" in the broader sense of the term (including innovation) (Wang 2013: 4). This corresponds most closely to what has traditionally been defined 
as "science and technological cooperation". From this perspective, science cooperation to promote science-related objectives is an end in itself. By contrast, science becomes a means to an end when speaking about "Science for Diplomacy (...): international engagement through science to develop, sustain, or enhance relationships between countries" (Wang 2013: 4). This understanding is about using science as a vehicle for attaining foreign policy objectives. While striving to refine the understanding of these two dimensions of science diplomacy by the EU, the analysis initially employs the terms "science diplomacy", "external science policies" and the traditional EU jargon “international S\&T cooperation" interchangeably.

\section{EU role conceptions in external science policies}

Defined as such, science diplomacy is subjected to a discourse analysis so as to understand which sorts of reasons EU policy-makers invoke for its expansion. To classify these reasons as expressions of discourse corresponding to either NPE or MPE, the article draws on role theory as originally developed by Holsti (1970). Role theory helps to develop a more nuanced investigation into the various functions the EU sees for itself in the science diplomacy domain. Its role conceptions can subsequently be classified according to their underlying logic of action, whether driven by norms or interests. This intermediate step provides an innovative way of operationalizing the NPE and MPE concepts through discourse-analytical tools.

Holsti argued that a "national role conception includes the policymakers' own definitions of the general (...) actions suitable to their state, and of the functions, if any, their state should perform on a continuing basis in the international system or in subordinate regional systems" (1970: 246). Role conceptions become thus policymakers' "“image' of the appropriate orientations or functions 
of their state toward, or in, the external environment" (Holsti 1970: 246). Although they do not "dictate every aspect of foreign policy behavior", "role performance results from, or is consistent with, policymakers' conceptions of their nation's orientations and tasks in the international system or (...) regional systems" (Holsti 1970: 298, 245). While originally restricted to national roles, role theory has been applied to other actors performing foreign policy tasks, such as the EU (Elgström/Smith 2006; Aggestam 2006). It therefore provides an adequate theoretical starting point for extracting EU self-perceptions of its science diplomacy, while also furnishing the necessary methodological bases for a discourse analysis.

In his study, Holsti presented a taxonomy of 17 role conceptions. Out of these, and in an effort at identifying those most suited for a contemporary EU context, 13 possible EU role conceptions were initially retained. ${ }^{3}$ At the same time, the discourse analysis remained open to reformulations and the emergence of other role conceptions. Taking inspiration from Holsti's methodology, at the most basic level, "the research procedure involved reading a large number of sources (...) and noting themes which gave evidence of the presence of (...) role conceptions" (Holsti 1970: 258). In terms of these sources, the analysis relied on 27 key strategic documents and speeches relating to EU external science policies and issued between the end of the Cold War in 1990 and 2015. These documents were selected on the basis of a broad mapping of Commission, Council and European Parliament documents relating to external science policy and represent those publicly

\footnotetext{
${ }^{3}$ Bridge, balancer, defender of the peace, developer, example, faithful ally, internal development, isolate, mediatorintegrator, protectee, regional leader, regional protector, regional-subsystem collaborator. Four role conceptions were excluded from the analysis because they were closely related to the bipolar Cold War context (e.g. "anti-imperialist agent").
} 
available strategies and papers, or speeches of high-level EU representatives, in which evidence of external science policy-related role conceptions were found. These documents fall into four categories:

- General science-related strategies: Council Conclusions (2013, 2008b), Commission Communications (2014, 2012b, 2008, 1995, 1990) and Commissioner's speeches explicitly dealing with international S\&T cooperation or science diplomacy (Moedas 2015a, 2015b; Geoghegan-Quinn 2013);

- Country- or region-specific strategies containing references to science: Commission Communications $(1997,1996)$ and speeches referring to cooperation with specific countries/regions (Geoghegan-Quinn 2012, 2010);

- ERA-related strategies: ERA-related documents (Council 2012, 2008a; Commission 2007, 2000) including on its international dimension (Commission 2001, Potocnik 2008a);

- Specific strategies with a bearing for EU external science policies: Council Conclusions (2010) and speeches related to knowledge (Potocnik 2008b, 2008c), the globalisation of R\&D (Potocnik 2005), research (Busquin 2002) or to cooperation with specific regions (Barroso 2011, Schulz 2014) when containing references to science.

Starting from the 13 role conceptions derived from Holsti's study, these documents were analysed in search of (i) predefined key terms corresponding to these conceptions and (ii) general motivations given for EU engagement in science diplomacy, which were gradually coded to arrive at the role conceptions discussed in section 3. Building on Holsti's methodology entailed engaging in a discourse analysis (Wodak 2008) characterised by an iterative process of going back and forth between Holsti's and newly emerging role conceptions and the empirical evidence. In this process, 
the coding of these conceptions was gradually refined, evidence was found for some of Holsti's conceptions, and new role conceptions were robustly defined and delimited. The analysis yielded nine role conceptions expressed by the EU in the context of its external science policies. Together with evidence of two of Holsti's original conceptions (developer; mediator-integrator), it generated two reformulated conceptions ${ }^{4}$ (contributor to peace, prosperity, stability and security; international collaborator for scientific or other purposes) and five new role conceptions (competitor; contributor to EU policies, objectives and interests; knowledge-based actor; partner in mutually beneficial cooperation; partner in tackling global challenges).

In a second step, the resulting set of role conceptions was classified according to whether they correspond to (i) an image of the EU as NPE or MPE, as outlined below, and (ii) a definition of science for diplomacy or diplomacy for science (see Figure 1 below).

\section{Relating EU role conceptions to MPE and NPE}

To classify the nine role conceptions according to whether they correspond to the conceptualisation of the EU as NPE or MPE, Damro's observation (2012: 697) that "ultimately, the best way to evaluate NPE versus MPE may be to determine whether the EU is more likely to influence the behaviour of others through the projection of its $(\ldots)$ norms or the externalization of its marketrelated policies and regulatory measures" provides the main starting point. Do these role conceptions correspond to a logic of action associated with norms and appropriateness (NPE) or

\footnotetext{
${ }^{4}$ Evidence was also found for a 'European stabilizer' role conception (stabilising regional order), primarily for the 1990s. Due to its historical character, this conception is not further developed here.
} 
to self-interested instrumentalism (MPE)? Four role conceptions were found to correspond to the notion of NPE, the remaining five corresponded to MPE.

The four role conceptions corresponding to the notion of NPE were found to be expressions of the EU referring to the norms that Manners argues lie at the heart of the EU's identity as evidenced by its key principles and objectives developed through treaties and policies (acquis communautaire et politique). The role conceptions of contributor to the peace, prosperity, stability and security (using international science cooperation to achieve these aims) and mediator-integrator (helping adversaries to reconcile or improve their dialogue, opening alternative channels of communication when other forms of diplomacy have failed) corresponded to Manners' core norms of peace and sustainable development. The role conception of partner in tackling global challenges (committed to addressing joint societal, political, demographic and environmental problems) fit above all Manners' minor norm of sustainable development. Finally, the role conception of developer (assisting countries in their socio-economic, scientific and technological development) evidenced the EU's identity as a promoter of all its key norms.

Five role conceptions emerging from this analysis are considered as expressions of MPE. According to Damro (2012: 697), “the EU's identity is not a particular set of collective norms but rather a comparatively large regulated market". EU external action, from an MPE perspective, is motivated by a desire to defend EU interests and promote its practices, policies and regulations globally. Although science is primarily a distributive, not a regulatory policy in the EU context, it represents an area in which the Union is - especially based on the ERA as internal market for knowledge and research with inter alia rules on the free movement of researchers, but also with 
the extensive rulebook that comes with the Framework Programme - clearly (desirous of) shaping rules and practices not only inside the Union, but also of projecting these externally to whoever wants to do science-related business with it (e.g. participate in EU-funded projects). For these reasons, it can be argued that the EU's "science market" identity lies at the heart of the following role conceptions: competitor (strengthening the EU's competitiveness, facilitating international trade, increasing the Union's market share through science); knowledge-based actor (pursuing scientific goals such as strengthening the EU's S\&T capabilities, extending the frontiers of S\&T knowledge or accessing S\&T knowledge/capacities outside Europe); and partner of mutually beneficial cooperation (pursuing such cooperation for instance to access other's research efforts). Moreover, the aims of externalizing market-related policies and practices or strengthening the EU's market basis through science are expressed via the role conception international collaborator for scientific or other purposes. In a broader sense, the emphasis of MPE on material elements determining the EU's identity and behaviour in international relations resonates with a logic of consequences, according to which "actors in the international system (...) seek to develop policies that allow them to maximise their own interest" (Sjursen/Smith 2004: 127). A final role conception referring to science based on such self-interested instrumentalism was detected: contributor to $E U$ policies, objectives and interests.

To validate these findings and verify if EU role performance is consistent with these role conceptions (Holsti 1970: 245), the discourse analysis is contrasted with a brief analysis of EU action in section 4 . 


\section{Policy-makers' motivations for an EU science diplomacy}

This section presents in more detail the evidence found for the nine role conceptions that emerged from the analysis of the EU's external science policies discourse. It discusses their relative importance and classifies them. Figure 1 provides an overview of these role conceptions and how they correspond to an image of the EU as NPE or MPE. It also shows whether these role conceptions correspond more closely to the "science for diplomacy" or "diplomacy for science" dimensions of science diplomacy.

Figure 1: Classifying EU role conceptions on science diplomacy

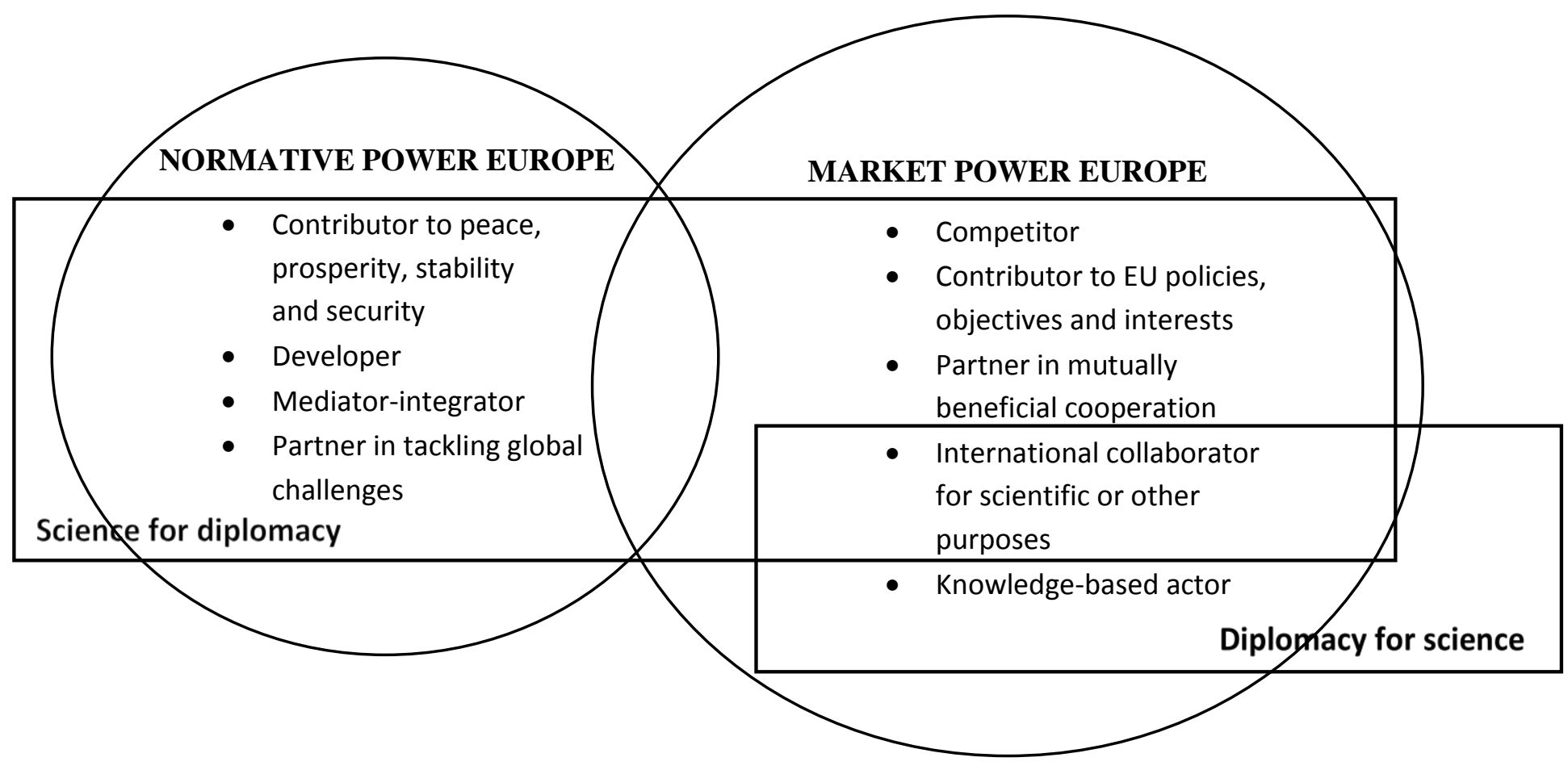

\subsection{Role conceptions corresponding to a NPE logic}

Role conceptions that correspond to NPE can above all be found in general strategies. In specific strategies, the EU refers to norms, and uses corresponding role conceptions, mostly when it speaks 
about its engagement on science in the context of international organisations, especially multilateral fora (such as the OECD), with developing countries, and specifically the Middle East. Evidence of the role conceptions developer and partner in tackling global challenges predominates. The former was referred to 44 times, the latter 35 times in the majority of documents from 1990 until 2015. Less evidence was found of the role conceptions contributor to peace, prosperity, stability and security (11 instances) and mediator-integrator (13 instances), which appear in documents from the 2000s onwards. The role conceptions are discussed in alphabetical order.

\section{Contributor to peace, prosperity, stability and security}

This role conception is inspired by Holsti's defender of the peace conception indicating "a universal commitment to defend against any aggression or threat to peace" (1970: 272), but has been expanded to also include prosperity, stability and security. EU discourse regularly mentions external science activities as means for attaining these interconnected objectives (Commission 2001: 9, 2008: 2, Moedas 2015a, 2015b), either in general strategies or in relation to specific partners. The following extract stands emblematically for a plethora of similar statements:

If it's a more peaceful, more prosperous world we wish to leave behind, the EU approach to diplomacy must use the elevated language of science for its remarkable uniting power (Moedas 2015b). 


\section{Developer}

This role conception refers to "a special duty or obligation to assist underdeveloped countries" (Holsti 1970: 266). Evidence of this role conception can be found in the EU's declared aim to use external science policies as a means to support the development of three groups of countries: developing, emerging and enlargement/neighbourhood countries.

First, EU policy-makers declare assisting developing countries in their socio-economic development both from a S\&T perspective - e.g. enhancing their research and innovation capacities (Geoghegan-Quinn 2013: 3; Commission 2008: 8, 1990: 10), strengthening their basic research (Commission 1990: 8), narrowing the technological gap (Commission 2008: 9, 1997: 11) - and in broader development terms, e.g. contributing to their sustainable development (Commission 2012b: 6, 1995: 20). A quote from a speech by Commissioner Potočnik (2005: 6) illustrates this objective:

we need to enhance S\&T cooperation with the Developing Countries. It is now largely recognized that the development of S\&T and innovation is one of the essential engines of socio-economic growth and sustainable development in the Developing Countries.

Second, in its relations with emerging economies, development objectives are explicitly mentioned, but combined with greater concern for competitiveness, pointing to a certain tension between a norms- and an interest-based EU motivation (e.g. Commission 1990: 9, 1995: 21):

the proactive deployment of Europe's S\&T strength in these countries could represent a powerful mechanism for achieving a substantial increase in the Union's market share. It will also contribute to the socio-economic development of the region by helping the partner countries to (...) learn from the experiences of the Union (Commission 1996: 3). 
More recent documents contain a greater focus on emerging economies as competitors (Geoghegan-Quinn 2013: 3).

Third, and still in an effort to promote third countries' development, EU policy-makers have traditionally sought to integrate enlargement/neighbourhood countries into the ERA (Commission 2012b: 6; Geoghegan-Quinn 2013: 3). The link between enhanced research capacity, the integration into the European scientific community/ERA and the preparation for accession was stressed regarding applicants (Commission 2000: 18), the Central European states (Commission 1995: 16), and has more recently been revived regarding the Western Balkans (Potocnik 2008b: $6)$.

\section{Mediator-integrator}

The mediator-integrator role conception corresponds to self-perceptions of a task to help adversaries reconcile their differences (Holsti 1970: 265). This role conception captures references to science cooperation as a means to help improve dialogue between certain countries (Commission 2001: 3), to open channels of communication or to keep such channels open when other measures have failed (Moedas 2015a, 2015b).

Apart from general statements, this role conception could increasingly be detected in recent statements (e.g. Commission 2014; Moedas 2015b), especially with regard to the Middle East:

All Middle Eastern countries are encouraged (...) to participate in Horizon 2020. Horizon 2020 also supports (...) the recently launched Middle East Research and Innovation Dialogue project (MERID), which employs research, science and innovation as channels for intercultural dialogue, understanding and reconciliation (Moedas 2015a). 
Partner in tackling global challenges

This role conception indicates a commitment to addressing major common global societal, political, demographic and environmental challenges, generally in pursuit of global public goods. Evidence of this role conception was found both in general statements on international science cooperation (Council 2013: 2-3, 2008b: 1; Moedas 2015b; Geoghegan-Quinn 2013: 3-4, 2012: 2; Commission 2012b: 4, 2008: 4, 2007: 3) and in country/region-specific statements, e.g. on emerging and industrialised countries (Commission 2012b: 6, 2008: 8, 1995: 19), Russia (Commission 2001: 9), developing countries (Commission 2012b: 6), the Middle East (Moedas 2015a), New Zealand (Barroso 2011: 3), the US (Geoghegan-Quinn 2010: 3) and the Western Balkans. In a speech held in Montenegro, for instance, Commissioner Potočnik (2008b) told his interlocutors:

Together, we will mobilise the brain-power of Europe to put knowledge and innovation at the service of people. Jointly, we will confront global challenges.

Altogether, these four role conceptions corresponding to an NPE logic all refer to the science for diplomacy dimension of science diplomacy that uses "international engagement through science to develop, sustain, or enhance relationships between countries" (Wang 2013: 4). Science is referred to as a means for cooperative purposes, attaining certain norms that the EU defends in the global context, especially fostering (sustainable) development and tackling global challenges. While prominent in general statements, and frequently referred to in documents related to specific countries, these four role conceptions appear overall less frequently in the EU's discourse than those corresponding to a MPE logic. 


\subsection{Role conceptions corresponding to a MPE logic}

Many general science-related statements contain references to role conceptions corresponding to MPE. Such conceptions appear particularly in contexts regarding neighbouring countries as well as emerging and industrialised countries that are S\&T heavyweights. The most frequently evoked role conceptions were competitor (59 times), contributor to EU policies, objectives and interests (57 times) and knowledge-based actor (46 times), followed by international collaborator for scientific or other purposes (38 times) and partner in mutually beneficial cooperation (23 times). Evidence of these role conceptions was found in documents from the entire period 1990-2015. They are again discussed in alphabetical order.

\section{Contributor to EU policies, objectives and interests}

This role conception captures the oft-invoked support that external science policies can give to EU policies, objectives or interests. Evidence of this role conception includes references to the importance and complementarity of international science cooperation for the Union's external relations, policies and instruments (Council 2013: 2; Commission 2014: 7, 2012b: 6; GeogheganQuinn 2013: 3), supporting other EU policies such as the common commercial policy:

International cooperation in research and innovation contributes to the broader policies of the Union, as reflected in the Europe 2020 strategy (Commission 2012b: 4).

Science diplomacy is as much about innovation in economic policy, as it is about neighbourhood policy, or even foreign policy (Moedas 2015a). 
This role conception also captures the need to develop international S\&T cooperation in close coordination with other policy instruments (Commission 2012b: 6) and for opening up the ERA internationally (Council 2013: 2, 2012: 3, 2008a: 2-3; Commission 2008: 2, 4, 2007: 3) for positioning Europe as a hub of the world-wide knowledge-based society (Commission 2001: 4) and for raising its profile in the world (Commission 2001: 7).

\section{Competitor}

The competitor role conception is frequently evoked in EU discourse, since finding the balance between cooperation and competition remains "the crucial question for international RTD" (Commission 1995: 4; Moedas 2015b; Geoghegan-Quinn 2010: 3; Potocnik 2005: 3). This conception strongly indicates an interest in using science for strengthening the Union's competitiveness in general terms (Busquin 2002: 4; Moedas 2015a, 2015b; Schulz 2014), including multiple allusions to the competitiveness of EU companies and industry (Council 2008b: 2; Commission 2012b: 4, 2008: 3, 8, 1996: 3), as well as to improving market access or the Union's market share (Council 2010: 10; Geoghegan-Quinn 2013: 3) and strengthening its position in international trade (Commission 1995: 1e):

international cooperation in research and innovation is vital to the strengthening of the Union's excellence and attractiveness in research and innovation as well as its competitiveness (Council 2013: 2).

Alongside general statements about international S\&T cooperation, one can also detect references to individual or categories of countries, with special emphasis on balancing cooperation and 
competition when referring to industrialised countries and on improving market access in industrialised, emerging and developing countries.

International collaborator for scientific or other purposes

The role conception Holsti called "regional-subsystem collaborator" indicated "far-reaching commitments to cooperative efforts with other states to build wider communities, or to crosscutting subsystems" (1970: 265). The reformulation into international collaborator for scientific or other purposes seeks to better capture the commitments to self-interested collaboration at the international level, not always aimed at a specific region/subsystem.

This role conception includes the importance of reinforcing S\&T cooperation per se (for scientific purposes, as "diplomacy for science") and also using it instrumentally for other, often economic purposes (as "science for diplomacy"). In both cases, general and country/region-specific statements were found. Examples abound of the importance of reinforcing S\&T cooperation in general terms (Potocnik 2005: 5-6; Council 2008b: 3, 2010: 10; Commission 2012b: 4) and with specific partners - e.g. Israel (Schulz 2014), the neighbours (Commission 2012b: 6), Australia (Geoghegan-Quinn 2012: 2) - as well as the importance of regular exchanges of views within the framework of international organisations to pursue interests (Commission 1995: 13).

This role conception captures in particular the instrumental use of science cooperation to further develop, improve and deepen relations (Moedas 2015b), trigger industrial cooperation (Commission 1996: 2, 6), boost trade and investment relationships (Geoghegan-Quinn 2010: 2) or pave the way for closer economic and political cooperation (Commission 2001: 3). One of many examples stresses 
the highly instrumental role that S\&T cooperation agreements may play in the setting up of new, structured relationships with these countries of particular strategic interest [emerging economies] for the Union (Commission 1996: 2).

\section{Knowledge-based actor}

This role conception refers to the pursuit of purely scientific and technological interests through international cooperation. EU discourse frequently mentions using international S\&T cooperation to achieve goals such as strengthening the S\&T capabilities of the European research community (Commission 1990: 2), strengthening the S\&T base of the EU (Council 2008b: 2), improving the performance of the Union's RTD (Commission 1995: 19), accessing knowledge (Commission 2007: 9-10; Geoghegan-Quinn 2013: 2-3), developing Europe's scientific excellence (Commission 2008: 2, 4, 2007: 9) and attracting "best scientific minds" to come and work in Europe (Geoghegan-Quinn 2012: 5).

It also includes references to extending the frontiers of S\&T knowledge (especially in multilateral contexts, Commission 1995: 13), sharing S\&T information (Council 2008b: 2; Commission 2007: 9-10) and raising the S\&T profile of Europe (Commission 2008: 3, 2001: 3), while making ERA a world class reference (Commission 2008: 3, 2001: 4).

Ultimately, this role conception perceives science diplomacy as diplomacy for science in the interest of further strengthening the Union's "science market". 


\section{Partner in mutually beneficial cooperation}

This role conception emphasises the importance of pursuing cooperation that is in the participating parties' mutual interest through international S\&T cooperation. Discourses falling under this role conception stress the importance of cooperation in mutually advantageous terms, based on reciprocal access to research efforts (Commission 1995: 4) and mutual access to market opportunities (Geoghegan-Quinn 2013: 2) as well as the reciprocal benefits deriving from cooperation (Council 2013: 3, 2010: 10). Both general and country-specific statements contain this role conception.

In synthesis, EU policy-makers make frequent use of the role conceptions corresponding to a MPE logic, referring to both major dimensions of science diplomacy. Several role conceptions correspond to diplomacy for science, evoking diplomatic means as useful for achieving scientific goals. The conceptions international collaborator for scientific or other purposes (when referring to international S\&T collaboration as an end in itself) and knowledge-based actor qualify as expressions of this dimension. These role conceptions perceive as the main purposes of the EU's external science policies a promotion of the external dimension of the EU's Framework Programme for Research and ERA, and thus an externalisation of the EU's "science market", mostly via what has classically been referred to as S\&T cooperation. By contrast, the role conceptions competitor, contributor to EU policies, objectives and interests, international collaborator for scientific or other purposes (when other, non-scientific purposes are stressed) and partner in mutually beneficial cooperation correspond to science for diplomacy. With these role conceptions, the EU intends "to capitalize intentionally on its market power to achieve foreign 
policy goals" (Jurje/Lavenex 2014: 325). These role conceptions perceive science and innovation as means for competitive purposes. Their underlying rationale, with the partial exception of contributor to EU policies, objectives and interests, could thus be captured by the notion of ‘science for economic diplomacy'.

\subsection{Complementary narratives for a reinforced EU science diplomacy}

The discourse analysis reveals, first and foremost, that EU policy-makers draw on a mix of rationales for their justifications of the Union's increased engagement in science diplomacy. Not only do NPE and MPE logics coexist, they are sometimes referred to in the same sentence of a strategy or speech, for instance when it comes to reconciling the need to cooperate with emerging economies while highlighting the competitive nature of the Union's relationship with them.

While the EU thus seems to be wanting to balance out this tension, and that is the second main insight, a clear pattern indicating more frequent recourse to an instrumentality-based as compared to a norms-based argumentation emerged from the analysis. This points to policy-makers' conscious or unconscious desire to justify policy expansion in this area predominantly on the basis of an "EU-as-(science) market power" theme rather than with reference to the general norms underpinning European integration.

Third, the analysis yielded a clearer picture of the conceptions held by policy-makers of the contents of EU science diplomacy. Evidently, the more traditional vision of science diplomacy as diplomacy for science - using diplomatic means to facilitate international science cooperation - 
continues to form a key component of EU discourse, which it has sought to rhetorically further strengthen recently. From this classical "international S\&T cooperation" perspective, the promotion of science through external action represents an end in itself. This dimension comprises in particular the intention of externalizing the EU's internal market (ERA), corresponding therefore to a MPE logic. However, and although already present in documents from the 1990s, the science for diplomacy dimension has gained more considerable ground in EU discourse recently. The analysis reveals, on the one hand, that EU policy-makers express a willingness to use science for attaining foreign policy objectives corresponding to a normative agenda, especially in terms of (sustainable) development and global challenges (NPE logic). On the other hand, they also highlight a possible instrumentalisation of science for advancing a broader (especially economic) agenda, e.g. for attaining greater competitiveness, market shares, but also other foreign policy goals. This corresponds to MPE and mirrors the framing of science and innovation policies inside the EU, which are discursively strongly connected to the "growth and jobs" theme permeating the Europe 2020 strategy.

\section{EU science diplomacy in practice}

The discourse analysis has resulted in the identification of three categories of EU science diplomacy - diplomacy for science corresponding to a MPE logic (the classical international S\&T cooperation narrative), science for diplomacy corresponding to a NPE logic (a narrative that employs science to promote essentially peace-building and (sustainable) development), and science for diplomacy corresponding to a MPE logic (a narrative employing science and innovation to promote mainly the EU's competitiveness) (see Figure 1). To validate if these images 
of EU science diplomacy conveyed in official statements (what the EU says) correspond to actual behaviour (what it does), a plausibility probe into EU activities is now undertaken. To this end, and while space constraints prevent an exhaustive discussion, a few illustrative examples of EU science for diplomacy and diplomacy for science are highlighted.

Diplomacy for science: the external dimension of the Framework Programme and ERA

EU diplomacy for science comprises three main forms of activities, mainly conducted by the Commission's Directorate-General (DG) for Research and Innovation.

First, the EU makes multiple usages of its framework programme to facilitate international science cooperation. Generally, all countries can participate in Horizon 2020.5 Moreover, especially for neighbourhood countries the possibility of becoming associated members to Horizon 2020 is foreseen, by which they obtain similar rights and obligations as EU Member States. The EU also tries to include its neighbours into a broader Common Knowledge and Innovation Space. Additionally, under the "Excellent Science" pillar of Horizon 2020, the European Research Council finances researchers from all over the world, provided they implement their projects in the EU.

Second, the EU engages in more than 40 bilateral Science, Technology and Innovation (STI) agreements with third countries ${ }^{6}$, which traditionally pursue primarily (but no longer exclusively,

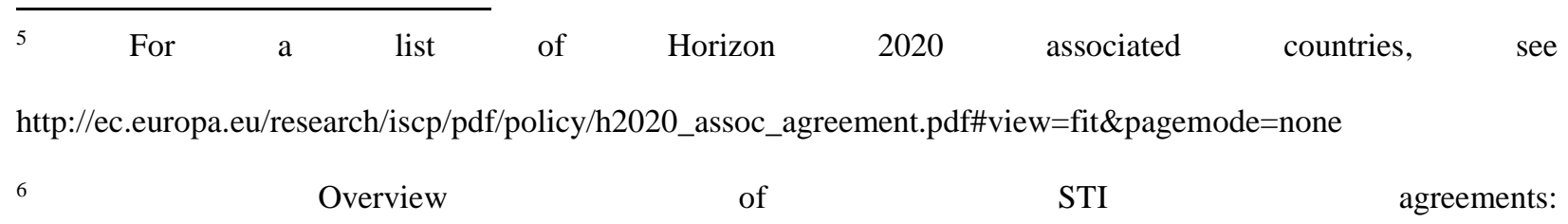

http://ec.europa.eu/research/iscp/pdf/policy/st_agreement_ec_euratom.pdf\#view=fit\&pagemode=none 
as argued below) science-related ends such as enhancing prospects for collaborative research or allowing for the shared use of research facilities (Fikkers/Horvat 2014). S\&T cooperation is also an important component of the various EU regional cooperation frameworks such as the Mediterranean Partner Countries (via the Monitoring Committee for Euro-Mediterranean cooperation).

Third, the EU supports multilateral activities, especially as part of the OECD's Global Science Forum or in the Global Research Council, an organisation formed by the heads of science/engineering funding agencies from around the world, so as to promote the sharing of data and other forms of collaboration among funding agencies worldwide. ${ }^{7}$ Such activities can be understood as the external promotion of ERA because they provide frameworks in which the Union can attempt to diffuse its internal rules and practices on how to organize scientific research. Additionally, ERA itself foresees direct international cooperation, e.g. via the creation of international infrastructures (Commission 2012a: 4).

Generally, the target countries of the EU's diplomacy for science correspond to its priority partners: (potential) candidate countries and other neighbours as well as strategic partners.

Science for diplomacy

EU science for diplomacy has arguably been less prominent and only recently on the rise. As it uses science for non-scientific foreign policy purposes, it involves a broader array of actors, including different Commission DGs such as Development Cooperation or Trade as well as the

\footnotetext{
${ }^{7}$ http://www.globalresearchcouncil.org
} 
European External Action Service (EEAS), which "closely works with the Commission (...) in order to (...) develop a genuine and ambitious science diplomacy” (EEAS 2015). A few examples corresponding to either a MPE logic or a NPE logic serve to illustrate the growing importance of this dimension.

In a MPE perspective, the most significant examples of what could be termed 'science for economic diplomacy' include the abovementioned STI agreements. The EU increasingly signs these agreements not only for scientific, but also for non-scientific reasons, especially with neighbourhood and developing countries. For Fikkers and Horvat (2014: 11, 13), the Union does so in order to support its external economic policies and competitiveness through science. The fact that STI agreements are used for promoting EU science-related objectives and non-scientific purposes mirrors the fuzziness with which allusions to various forms of science diplomacy are mingled in EU science diplomacy-related discourse.

From the NPE perspective, instances of using science to support the EU's norm-driven foreign policy traditionally involve partnerships with developing countries such as the Africa-EU Partnership, a long-term framework for structured cooperation. ${ }^{8}$ In recent years, specific initiatives corresponding to this logic have however also been launched. They are particularly targeted at the Middle East. Examples include the EU's substantial financial and technical support to SESAME (Synchrotron-light for Experimental Science and Applications in the Middle East), a platform initiated in 2004 under the auspices of the United Nations Educational, Scientific and Cultural Organisation - and modeled on the European Organization for Nuclear Research (CERN) - in

\footnotetext{
${ }^{8} \mathrm{http}: / /$ www.africa-eu-partnership.org/en/areas-cooperation/science-info-society-space/depth
} 
order to foster a scientific cooperation culture and promote dialogue in the Middle East. ${ }^{9}$ Where the EU merely reinforces a UN initiative in the case of SESAME, the Middle East Research and Innovation Dialogue project, which is supported under Horizon 2020, represents an example of a genuine EU initiative that seeks to encourage research cooperation through the collaboration amongst researchers and policy-makers from all countries in the region. ${ }^{10}$

Altogether, this necessarily brief plausibility probe of EU science diplomacy activity patterns appears to confirm the results of the discourse analysis. While further detailed scrutiny will be needed to solidify this finding, the EU seems to be in a process of consolidating its diplomacy for science, based on an instrumental, science and innovation-oriented logic, but it also appears to be reinforcing its science-based cooperation with third countries for the purpose of pursuing broader foreign policy objectives. The implications of these findings are discussed in the conclusion.

\section{Conclusion}

This article set out to provide a detailed understanding of the motivations for the EU's evolving science diplomacy, which was treated as a hard case for examining the validity of considering the EU as either a market or a normative power. The study drew on a discourse analysis that identified nine role conceptions expressed by EU policy-makers in the external science policy domain, which were validated through probing its concrete behaviour. This yielded a number of novel insights in empirical and conceptual terms, which have strong policy implications.

\footnotetext{
9 http://www.sesame.org.jo/sesame/

10 http://meridproject.eu/
} 
For one, the analysis provided ample evidence that and how the EU is indeed - both rhetorically and in its actions - promoting its science diplomacy. Its findings help clarify the understanding that policy-makers have of the contents of EU science diplomacy. They suggest that the Union is in the process of reinforcing its diplomacy for science (the classical international S\&T cooperation), while developing a genuine science for diplomacy. These latter efforts correspond, on the one hand, to a MPE logic, and are aimed at capitalising on the EU's market power in the science domain to either increase its market share or attain other, often economic foreign policy objectives in line with the key purposes of Europe 2020. On the other hand, recent EU science for diplomacy initiatives also correspond to a NPE logic. They involve Commission attempts, supported by the EEAS, to advance a normative foreign policy agenda related primarily to peacebuilding and sustainable development. Ultimately, this analysis finds that these three variants form part of a broader, evolving EU science diplomacy landscape.

Additionally, the findings of this analysis advance the NPE/MPE debate in two main ways. On the one hand, they demonstrate the analytical salience of distinguishing between interest- and normdriven behaviour when it comes to EU external action. To justify EU policy expansion in the domain of science diplomacy, EU policy-makers primarily rely on discourses that refer to the Union's image as MPE, invoking instrumentalist rationales for investing into this activity. This suggests a certain need to frame policies in economic terms, a tendency that is mirrored in the way science and innovation are understood across the entire Horizon 2020 programme, namely primarily as a contribution to the Union's Europe 2020 agenda for growth and jobs. However, in more recent years, references to the EU's norms-based agenda have become more frequent, resulting in a peculiar mix of arguments for reinforced EU science diplomacy. This seems to imply that the use of a combination of discourses - addressed to different audiences - to justify novel 
external science policy activities may enhance the latter's acceptability. Put simply, EU science diplomacy means different things to different constituencies: traditionalists and purists caring about STI per se may find themselves in the reinvigorated classical S\&T narrative of diplomacy for science, those interested in strategically exploiting the economic potential of EU STI at a global scale will buy into the framing of science for economic diplomacy, and those - like the EEAS who see the potential of using science for other, primarily developmental or peace-building purposes will prefer the NPE framing of science for diplomacy. This multitude of framings thus serves to enlarge the supporter base for the expansion of this policy area.

On the other hand, if this discursive mix is seen in conjunction with the insights on how the EU actually operates in this policy area, the Union clearly seems to qualify at the same time as MPE and NPE in the external science policy domain. The contribution that this analysis makes to the EU external relations literature is thus to provide evidence that MPE and NPE are far from mutually exclusive, neither when it comes to EU rhetoric nor action. This insight underscores that “normative and market power approaches privilege different faces of what the EU's core identity is and emphasise different mechanisms through which European rules radiate beyond EU borders" (Lavenex 2014: 887). While a more detailed scrutiny of EU science diplomacy practices than could be provided here would be desirable to consolidate this finding, more analyses of "hard cases" of EU external policies would generally be needed to further investigate the interrelations between NPE and MPE.

Finally, these findings have policy implications. Not only do norms and interests co-exist in EU policy-makers' words and deeds, but there exists also a tension between them, namely how to choose whether to advance interests or norms (or how to reconcile them) in a given policy context. The June 2016 EU Global Strategy, with its call for "principled pragmatism” provides only an 
enigmatic response to this question: "Our interests and values go hand in hand. We have an interest in promoting our values in the world. At the same time, our fundamental values are embedded in our interests" (EEAS 2016: 9). EU (science) diplomats will need to be clearer in their interactions with various groups of interlocutors and based on scarce resources, and while norms might - as seen in the science domain - increasingly be alluded to, EU interests might well be what they will defend in practice.

\section{Bibliography}

Aggestam, L (2006) "Role theory and European foreign policy. A framework of analysis". In Elgström, O. \& Smith, M. (eds.) The European Union's Roles in International Politics. Concepts and Analysis (London: Routledge), 11-29.

Barroso, J. M. (2011) "The European Union - a Committed Partner for New Zealand and the Pacific". Auckland University, 8 September.

Busquin, P. (2002) "Research in Europe". Edinburgh, 28 October.

Commission (1990) Cooperation in Science and Technology with Third Countries. COM (90) 256 final.

Commission (1995) Perspectives for International Cooperation in Research and Technological Development. COM (95) 489 final. 
Commission (1996) Promoting RTD Cooperation with the World's Emerging Economies. COM (96) 344 final.

Commission (1997) Scientific and Technological Research - a Strategic Part of the European Union's Cooperation with Developing Countries. COM (97) 174 final.

Commission (2000) Towards a European Research Area. COM (2000) 6 final.

Commission (2001) The International Dimension of the European Research Area. COM (2001) 346 final.

Commission (2007) Green Paper: The European Research Area: New Perspectives. COM (2007) 161 final.

Commission (2008) A Strategic European Framework for International Science and Technology Cooperation. COM (2008) 588 final.

Commission (2012a) A Reinforced European Research Area Partnership for Excellence and Growth. COM (2012) 392 final.

Commission (2012b) Enhancing and Focusing EU International Cooperation in Research and Innovation: A Strategic Approach. COM (2012) 497 final. 
Commission (2014) Report on the Implementation of the Strategy for International Cooperation in Research and Innovation. COM (2014) 567 final.

Commission (2016) Open Innovation, Open Science, Open to the World - a vision for Europe.

Council of the European Union (2008a) Launch of the "Ljubljana Process"- Towards Full Realisation of ERA, 29-30 May.

Council of the European Union (2008b) A European Partnership for International Scientific and Technological Cooperation, 2 December.

Council of the European Union (2010) Innovation Union for Europe, 26 November.

Council of the European Union (2012) A reinforced European Research Area Partnership for Excellence and Growth, 11 December.

Council of the European Union (2013) Enhancing and Focusing EU International Cooperation in Research and Innovation: A Strategic Approach, 29-30 May.

Damro, C. (2012) "Market power Europe”, Journal of European Public Policy, Vol. 19, No. 5, 682-699. 
Duchêne, F. (1972) “Europe's Role in World Peace”. In Mayne, R. (ed.) Europe Tomorrow: Sixteen Europeans Look Ahead (London: Fontana), 32-47.

EEAS (2016) Shared Vision, Common Action: A Stronger Europe - A Global Strategy for the European Union's Foreign and Security Policy. June 2016.

Elgström, O. \& Smith, M. (eds.) (2006) The European Union's Roles in International Politics. Concepts and Analysis (London: Routledge).

Fikkers, D.J. \& Horvat, M. (eds.) (2014) Basic Principles for Effective International Science, Technology and Innovation Agreements (Brussels: European Commission).

Flink, T. \& Schreiterer, U. (2010) "Science and diplomacy at the intersection of S\&T policies and foreign affairs: toward a typology of national approaches", Science and Public Policy, Vol. 37, No. 9, 665-677.

Geoghegan-Quinn, M. (2010) "Tapping Research and Innovation for Jobs and Growth: Strengthening EU-US Cooperation in Research, Innovation and Science”. Washington, 1 June.

Geoghegan-Quinn. M. (2012) "Strengthening EU-Australian Cooperation in Research and Innovation". Canberra, 7 March. 
Geoghegan-Quinn, M. (2013) “Science: Global Challenges \& Global Collaboration”. Brussels, 5 March.

Holsti, K. (1970) "National Role Conceptions in the Study of Foreign Policy", International Studies Quarterly, Vol. 14, No. 3, 233-309.

JEPP (2015) “Special Issue: The European Union as a global regulator?", Journal of European Public Policy, Vol. 22, No. 9.

Jurje, F. \& Lavenex, S. (2014) “Trade Agreements as Venues for 'Market Power Europe'? The Case of Immigration Policy”, Journal of Common Market Studies, Vol. 52, No. 2, 320-336.

Lavenex, S. (2014) "The power of functionalist extension: how EU rules travel", Journal of European Public Policy, Vol. 21, No. 6, 885-903.

Lord K. \& Turekian V. (2007) “Time for a new era of science diplomacy”, Science, Vol. 315, No. $5813,769-770$.

Manners, I. (2002) “Normative Power Europe: A Contradiction in Terms?", Journal of Common Market Studies, Vol. 40, No. 2, 235-258.

Moedas, C. (2015a) “Addressing Shared Challenges through Science Diplomacy". Kingdom of Jordan, 13 April. 
Moedas, C. (2015b) “The EU Approach to Science Diplomacy”. Washington, 1 June.

Moedas, C. (2016) “Science Diplomacy in the European Union”, Science \&Diplomacy, Vol. 5, No. 1.

Potocnik, J. (2005) “How Europe can benefit from Increased Globalisation of R\&D”. Stockholm, 27 October.

Potocnik, J. (2008a) “An Open Space for Research and Innovation”. Ljubljana, 6 June.

Potocnik, J. (2008b) "Progress and the Knowledge Triangle in South Eastern Europe". Budva, 3 July.

Potocnik, J. (2008c) "Knowledge-Based Growth: Keeping on Course in Turbulent Waters". Brussels, 26 November.

Prange-Gstöhl, H. (ed.) (2010) International Science and Technology Cooperation in a Globalized World: The External Dimension of the European Research Area (London: Edward Elgar).

Royal Society (2010) New Frontiers in Science Diplomacy: Navigating the Changing Balance of Power (London: Royal Society). 
Schulz, M. (2014) "Speech to the Knesset”, 12 February.

Sjursen, H. \& Smith, K.E. (2001) "Justifying EU Foreign Policy: The Logics Underpinning EU Enlargement”. ARENA Working Papers WP 01/1.

Wang, T.C. (2013) "The Evolution and Future of Science Diplomacy: A U.S. Perspective". Presentation at the University of Tokyo, 27 June.

Wang, T.C. (2014) Science Diplomacy: Transatlantic Asset and Competition (Baltimore, MD: Johns Hopkins University).

Whitman, R.G. (ed.) (2011) Normative Power Europe. Empirical and Theoretical Perspectives (Basingstoke: Palgrave Macmillan).

Wodak, R. (2008) “Introduction: Discourse Studies - Important Concepts and Terms”. In Wodak, R., and Krzyzanowski, M. (eds.) Qualitative discourse analysis in the Social Sciences (Basingstoke: Palgrave), 1-29.

Youngs, R. (2004) "Normative Dynamics and Strategic Interests in the EU's External Identity", Journal of Common Market Studies, Vol. 42, No. 2, 415-435. 